\title{
Development of Remote-Type Haptic Catheter Sensor System using Piezoelectric Transducer
}

\author{
Mineyuki Haruta Non-member (Nihon university, g13409@ee.ce.nihon-u.ac.jp) \\ Yoshinobu Murayama Non-member (Nihon university, murayama@ee.ce.nihon-u.ac.jp) \\ Sadao Omata Member (Nihon university, omata@ee.ce.nihon-u.ac.jp)
}

Keywords : Phase shift, Haptic, Catheter, IVUS, Ultrasound

\section{Introduction}

Minimally invasive treatment, such as a catheter treatment, has been successfully applied for cardiovascular disease. Therefore, many types of a catheter was developed in specialized treatment. IVUS (intravascular ultrasound) is one of the catheter which give us some information inside and outside blood vessel, however, though the catheter is in the vessel no catheter bring us physiological information of the vessel - hardness. In this study, we developed a remote haptic type catheter sensor using tactile sensing technology, which can quantitatively evaluate the hardness of living tissues.

\section{Principle}

The measurement principle can be explained by correlating the resonance phenomena of the sensor from the acoustic system to the mechanical vibration model, thereby eliciting the relationship between the acoustic impedance, which is a tactile characteristic of the measurement object, and the phase shift.

The phase shift of the reflected wave from the object is decided by the propagating medium and the acoustic impedance of the object. By measuring the phase of the output electrical signal of the PZT, it is possible indirectly to ascertain the acoustic impedance of the object.

\section{Sensor}

The Remote Haptic Type catheter sensor comprises PZT disposed in direction on the outside of the catheter, mounted on silicone rubber.

\section{Measurement}

A blood vessel phantom ((Fig.1) was made, and experiments conducted on the utility of the sensor. The experiment consisted of positioning a PZT so as to pass through the tumor at a position $1 \mathrm{~mm}$ removed diametrically in a blood vessel phantom filled with water, moving the sensor $24 \mathrm{~mm}$ away in $0.1 \mathrm{~mm}$ steps, and measuring the phase of the sensor at each step.

Fig. 2 shows measurement result of blood vessel model. The bulk modulus rose to a maximum of $5.14(\mathrm{GPa})$ between the movement positions $7.6 \mathrm{~mm}$ and $16.5 \mathrm{~mm}$. Therefore, the acoustic impedance of blood vessel can be expressed as 3-D figure.

\section{Conclusion}

In this research, verification experiments were carried out on a catheter type sensor for remote tactility measurement. The measurement method consists of indirectly measuring the acoustic impedance, which is a characteristic of the hardness of an object, by using the change in phase of the sensor. The basic experiments show that there is a proximal relationship between the phase characteristics of the sensor and the acoustic impedance of the object. In addition, the blood vessel phantom experiment clearly showed the difference between the normal part and the tumor. Therefore, this research suggested the possibility of using a catheter type sensor which can ultrasonically measure intravascular tactility.

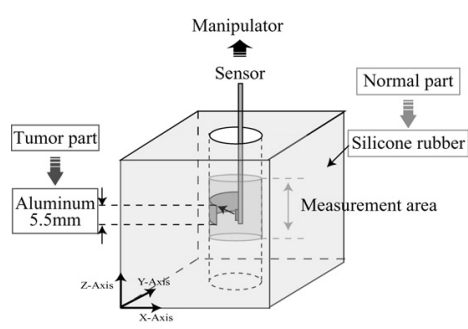

Fig. 1. Blood vessel phantom

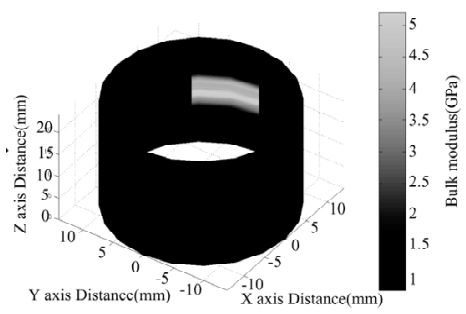

Fig. 2. 3D bulk modulus image 


\title{
圧電セラミック素子を利用した Remote Haptic 型カテーテルの 開発に関する基礎的研究
}

論 文

\author{
非会員 春田 峰雪* 非会員 村山 嘉延** \\ 正 員 尾股 定夫**
}

\section{Development of Remote-Type Haptic Catheter Sensor System using Piezoelectric Transducer} Mineyuki Haruta*, Non-member, Yoshinobu Murayama**, Non-member, Sadao Omata**, Member

This study describes the development of Remote-Type Haptic Catheter Sensor System which enables the mechanical property evaluation of a blood vessel. This system consists of a feedback circuit and a piezoelectric ultrasound transducer, and is operated based on a phase shift method so that the entire system oscillates at its inherent resonance frequency. Ultrasound reflected by the blood vessel makes a phase shift of the resonance system depending on the acoustic impedance of the reflector. The phase shift is then measured as a change in resonance frequency of the system; therefore, the detection resolution is highly improved. The correlation between the acoustic impedance and the resonance frequency change of the sensor system was demonstrated using silicone rubbers, metals and actual blood vessels from a pig. The performance of the sensor was also examined using vessel shaped phantom model. Finally, the discussion surveys a possibility of the novel sensor system in an application for intra vascular diagnosis.

キーワード : 位相シフト, 触覚, カテーテル, IVUS, 超音波

Keywords : Phase shift, Haptic, Catheter, IVUS, Ultrasound

\section{1. 背 景}

死因別簡易分類調査結果（平成 17 年人口動態調査）によ れば，現在の日本では血管疾患が $42 \%$ も占めている。なか でも，血管疾患である動脈硬化は，一般に血管内部の局所 的変性であり, エラスチンの質的変化や脂質, カルシウム 等の沈着などにより複合的に血管弾性 ${ }^{(1)}$ (3) が変化すること が知られている。さらに, 動脈硬化の特徵であるアテロー ム状の組織変性や繊維化, 石灰化, 壊死などは血管内部組 織の粘弾性，すなわち硬さや軟らかさが疾患によって異な ることが臨床現場では良く知られている。

そこで，このような動脈硬化病変をそれぞれの疾患レ心゙ ルで定量的に評価・診断する為の新しい計測法や分析法の 開発研究が積極的に進められている(4)。

近年, 血管動脈壁の性状を把握する為の新しい診断法と

* 日本大学大学院工学研究科電気電子工学専攻 干963-8642 福島県郡山市田村町徳定字中河原 1 Omata Labs.,

1 Naka-gawara, Tokusada, Tamura-machi, Koriyama-City, fukushima 963-8642

** 日本大学工学部電気電子工学科

Omata Labs.,

1 Naka-gawara, Tokusada, Tamura-machi, Koriyama-City, fukushima 963-8642
して，血管内超音波や血管内視鏡などが開発され急速な進 歩を遂げている。特に, 血管内検査用として開発された超 音波内視鏡型の IVUS ${ }^{(5)}$ (Intravascular Ultrasound）は, 動脈 硬化に対する薬剤評価法をはじめとしてインターベンショ ン後の再狭窄の診断, プラークの性状を把握する為の評価 法などに有効とされ，急速に注目されている。しかしなが ら, 血栓と脂質が関与する急性冠症候群（ACS）を定量的に 検討するには限界もあることが知られ, 更なる改良が求め られている(6)

一方，プラークの色調や形態的な特徽を評価するために 光ファイバーを利用した先端的な血管内視鏡法が開発され て, プラークの診断法の構築が進められているが, 血管内 での観察視野が狭いことや, 血球で光が乱反射して精度の 高い画像が得にくいなどの問題から不安定プラークの同定 にも限界があることが報告されている(7)。

以上のように血管内超音波や光を利用した血管内視鏡に よって血管壁の特性を形態的に観察する手法にも一長一短 があることから，両者の手法を融合して補完する診断法も 検討されている( ${ }^{(8)}$ 。また, 血管側壁の特性を観察する従来の IVUS と異なる手法として, 前方の視野を確保しながら高分 解能で画像化する超音波内視鏡 ${ }^{(9)}$ の開発研究も行われ, 今後 
の研究成果が期待されている。

ところで, 超音波の特徴を利用した後方散乱や高周波領 域での吸収特性などを利用して血管壁の物理的な特性，す なわち硬さや軟らかさを評価して画像化する血管弾性評価 システムとして IB-IVUS (Integrated Backscatter Intravascular Ultrasound) ${ }^{(10)}$, VH-IVUS (Virtual Histology Intravascular Ultrasound) ${ }^{(11)}$ などの開発も行われ, 臨床現場からも注目され ている。しかし，現段階においてこのような手法によって 血管壁の物理的な特性を評価するには，血管内での超音波 の反射特性や吸収特性, 後方散乱特性などを定量的に解析 する手法が必要となるが, 血栓の定量的診断法が十分に構 築されていない。だが, 一方で血管内壁の物性を検出して ヤング率や弾性率として, 硬さや軟らかさの画像化に関す る手法の実現も待望されていることから，IVUS Elastography ${ }^{(12)(13)}$ の開発研究が行われている。

そこで, 本研究室においても皮膚や血管のような軟組織 の物性をばね定数やヤング率として計測し, 硬さや軟らか さとして画像化するための新しい評価法の提案(14) (16)を行 っているが, 血管内に挿入可能なカテーテル型の弾性評価 システムの開発研究も行ってきた。

本システムに導入されている基本原理は，超音波放射振 動子と反射波を受信する受波振動子で構成された 2 枚の圧 電セラミック素子と位相シフト回路による強制帰還型発振 回路系で構成されている。この計測システムの最大の特徴 は, 生体のような軟組織の特性を触診のように硬さや軟ら かさとして検出されるので, 触覚センサ素子への応用や触 覚特性の画像化, 新しい医療機器開発への応用が試みられ ている。また，このシステムは高感度で高い S/N 比を有し ているので，体外受精卵の硬さをヤング率として評価する システムも実現されている。

このような，位相シフト型の計測システムは，圧電セラ ミック素子型の触覚センサを対象物体に接触して計測する のであるが，センサ素子を水中に適用して非接触法でシリ コーンゴムなどの物性計測に関する基礎的な実験を行い検 討した事例も報告されている(17) (19)。この新しい非接触法に よるセンサシステムは, 対象物体の音響インピーダンスに 依存して反射する超音波の振幅と位相特性が，受波用セン サの持つ共振特性に影響を及ぼすことを利用したシステム で, 計測結果はトポグラフィー (Topography) 画像として表 示される。

これらのことから, 本研究では, 非接触法で対象物体の 硬さや軟らかさを計測できる利点をいかしながら，触覚 (Haptic) のような特性を持つ計測原理をカテーテルに導入 して, Remote Haptic 型のカテーテルとして試作開発を行い, その基本的な特性と非接触法での検出の可能性をモデル実 験により検証し, 高機能型カテーテルの可能性について検 討した。特に, Remote Haptic 型のカテーテルの最終目的は, 次世代型カテーテルの試作開発と動脈硬化の原因でもある 血栓やプラークの同定にあるが，本研究論文では位相シフ ト型カテーテルの試作を行い, 次に石灰化のような硬い異
物モデルの検出やブタ動脈血管組織の計測の可能性, およ び硬さの画像化などについて基礎的な検討を行っている。

\section{Remote Haptic 型計測システムの原理}

Remote Haptic 型カテーテルのセンサ部には超音波を放射 する送信部と反射波を検出する受波部で構成された 2 枚の 圧電型セラミック素子 (PZT) を使用し, 帰還回路には位相 シフト回路を組み込むことでセンサの位相特性を利用した 強制帰還回路系の発振回路で構成されている。発振状態に おける PZT の駆動部からは試料に対して送信波が放射され， 試料の影響を受けた反射波は検出部である受波素子により 検出される。このときの反射波は試料の特性と伝播媒体の 音響インピーダンスによって影響を受け受波素子の共振特 性に影響を及ぼすので, このときの変化量を高精度で検出 できるシステムとして実現すれば，新しい Remote Haptic 型 カテーテルが試作開発できる。

〈2・1〉位相と音響インピーダンスの関係 触覚セン サ部となる PZT の共振現象は, 図 1 の音響系から機械系振 動モデルへの対応によって, 等価的にその性質を説明でき $ろ^{(14)}$ 。

音響系振動子の送信波 $\left(P_{I}\right)$ 及び反射波 $\left(P_{R}\right)$ の関係 ${ }^{(20)}$ は, 次 式により簡単に表せる。

送信波 : $P_{I}=P_{i} \sin (\omega t)$

反射波 : $P_{R}=R P_{i} \sin (\omega t+2 x \cdot \beta)$

ここで反射係数 $R$ は(3)式, 媒質定数 $\beta$ は(4)式である。

$$
\begin{aligned}
& R=\frac{Z_{2}-Z_{1}}{Z_{2}+Z_{1}} \\
& \beta=\omega \sqrt{\frac{\rho}{K}} .
\end{aligned}
$$

ただし， $Z_{1}$ は伝播媒質の音響インピーダンス， $Z_{2}$ は試料 の音響インピーダンスであり, $P_{i}$ は反射波音圧の強さ, $\omega$ は 駆動角周波数, $\beta$ は媒質定数を示し, $x$ は一様伝播媒体中で の送信波素子から対象物体までの音波の伝播距離, $\rho$ 及び $K$ は伝播媒質の密度及び体積弾性率を示す。

超音波を放射する素子に交流信号を印加すると受波素子 は常に送信素子の影響を受けるため, 受波素子の出力信号 は送信波と反射波の和として出力される。従って, 機械系

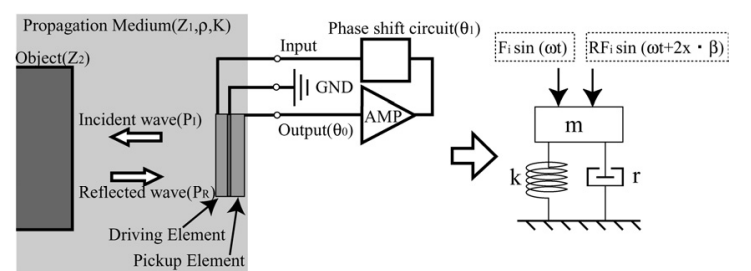

(a) Acoustic model

(b) Mechanical vibration model

図 1 圧電型セラミック素子による Remote Haptic 型センサ の音響系及び機械系振動モデルの対応

Fig. 1. Schematic diagram an acoustic model and a mechanical vibration model of Remote-Type Haptic Sensor 


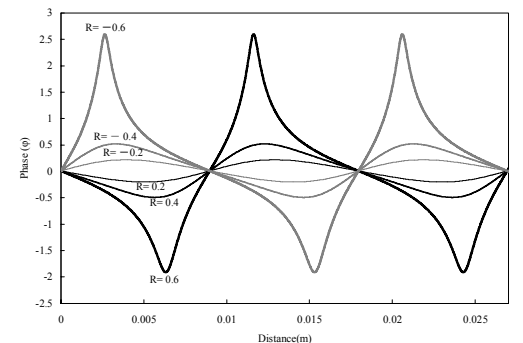

図 2 位相変化の様子

Fig. 2. Phase shifts with different reflection coefficient

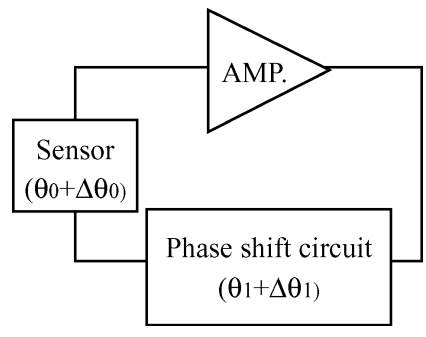

図 3 位相シフト法による発振回路構成 図 4

Fig. 3. Oscillation circuit of phase shift circuit

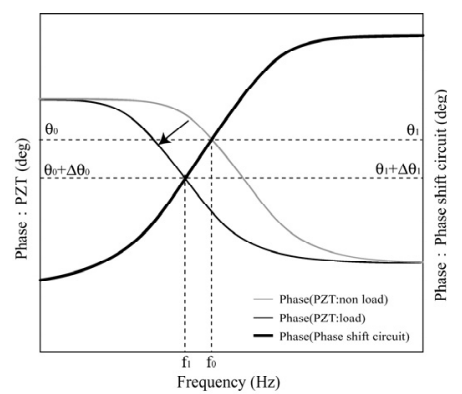

位相シフト法における位相変化の

様子

Fig. 4. Change in phase curve

response of phase shift method
振動モデルへ対応させた等価的な運動方程式は容易に表せ るが，送信波振幅 $P_{i}$ 及び反射波振幅 $R P_{i}$ は外力 $F_{i}$ 及び $R F_{i}$ に等価的に対応できるので，単自由度系における質量を $m$, バネ定数を $k$, 粘性係数を $r$ とすると，(5)式となる。

$$
F_{i} \sin (\omega t)+R F_{i} \sin (\omega t+2 x \cdot \beta)=m \frac{d^{2} x}{d t^{2}}+r \frac{d x}{d t}+k x
$$

ここで，（５)式は単自由度系の運動方程式であるが，送信 波音圧の伝播媒質の特性，反射波音圧の試料と伝播媒質の 特性の影響を含んだ系として等価的に扱うことができる。

また, 運動方程式( 5 )式における一般解は( 6 )式として示 される。

$$
x=A \sin (\omega t-\phi)
$$

ここで粘弾性による位相遅れ $\phi$ は( 7 )式となる。

$$
\phi=\tan ^{-1} \frac{r \omega-\left(k-m \omega^{2}\right) \tan \theta_{1}}{\left(k-m \omega^{2}\right)+r \omega \tan \theta_{1}}
$$

また，

$$
\theta_{1}=\tan ^{-1} \frac{R F_{i} \sin (2 x \cdot \beta)}{F_{i}+R F_{i} \cos (2 x \cdot \beta)}
$$

従って，受波素子により検出される粘弾性による位相遅 れфは送信波の音圧の強さ, 反射波の音圧の強さ, 対象物と の距離により決まる。しかし，本システムによって同一媒 体中で計測すると仮定すると，このときの位相差 の音圧と伝播媒体の特性及び対称物体との距離を一定のと き対象物体からの反射波音圧を受波素子の位相変化として 検出することができる。

図 2 は伝播媒質の内部減衰を考慮しないとき, すなわち $\beta=1$ での距離に対する位相 $\phi$ の変化を示す。ここで超音波が 対象物体に入射して反射する場合，このときの反射特性は 対象物体の音響インピーダンスによって決まることから， 送信波が伝播媒質を伝わるときの音響インピーダンスを $Z_{1}$, 反射波が生じる対象物体の音響インピーダンスを $Z_{2}$ と すると, $Z_{1}<Z_{2}$ の場合, 反射係数が正となるので, 境界面で の位相差 す。また, $Z_{1}>Z_{2}$ の場合, 境界面での位相が逆相となるので, 薄い実線のように示される。また，これらの計算結果には 伝播媒質の減衰特性が考慮されていないので, 図のように
定在波の位相振幅が距離に関係なく同じ振幅特性として示 されているが，血管や生体に適用した場合には，超音波の 吸収減衰があるので, 計測距離の増加と共に減衰特性も大 きくなることが予想される。しかしながら, 図のような位 相特性を利用することによって, 対象物体と伝播媒体との 音響インピーダンスが異なることから対象物体の物理的な 特性も計測することが可能となる。従って, 伝播媒体とな る血液および対象物体である血管壁の物性特性の違いから 生じる音響インピーダンスの位相差特性を利用することに よって, 対象物体の物理的な特性, 即ち硬さや軟らかさを 求めることが十分期待できる。

特に, 本研究で提案している位相シフト法は, 上記のよ うな位相特性を受波素子で検出して, この出力信号を送信 素子の入力端子に強制帰還するが, 回路系全体が帰還型発 振回路となるよう位相シフト回路が設けてある。

〈2·2〉 位相シフト法 図 3 に示寸位相シフト法はセ ンサ, 反転増幅器, 位相シフト回路で構成された帰還型発 振回路であり，閉ループ発振を行うため $\mathrm{S} / \mathrm{N}$ 比が向上する。 PZT で構成されるセンサ部は超音波を放射する送信部と反 射波を受信する受波部で構成されるが, センサの出力信号 の位相を $\theta_{0}$, 位相シフト回路の位相を $\theta_{1}$ としたときの発振条 件は，強制帰還型発振回路と同様に(9)式となる。

$$
\theta_{0}+\theta_{1}=0
$$

ここでセンサに負荷が加わった場合, センサの出力信号 における位相が $\left(\theta_{0}+\Delta \theta_{0}\right)$ に変化し, 位相シフト回路の位相 が $\left(\theta_{1}+\Delta \theta_{1}\right)$ において発振条件を満たし(10)式となる。

$$
\left(\theta_{0}+\Delta \theta_{0}\right)+\left(\theta_{1}+\Delta \theta_{1}\right)=0
$$

これらの位相特性と周波数特性の概略を示したのが図 4 で, 発振状態であるセンサが, 反射波の音響インピーダンス 特性に応じて位相が変化すると, このときの発振周波数も共 振条件を満足するように位相を補正しながら追従すること によって周波数シフトが生じる。従って, 反射波の特性に応 じて位相シフト回路が動作するので, わずかな位相シフトで あっても共振周波数の周波数シフトが $1 \mathrm{~Hz}$ レベルでも扱う ことが可能となるので検出分解能の向上が図れる。 


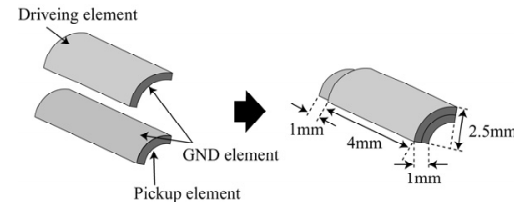

図 5 (a) PZT の構成

Fig. 5. (a) PZT structure

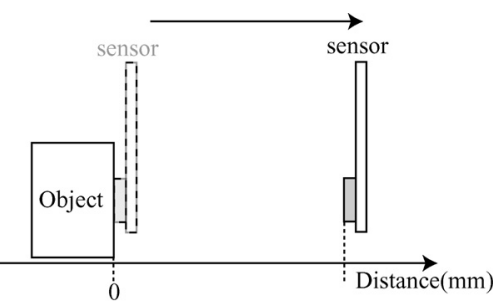

図 7 計測方法

Fig. 7. Measurement method

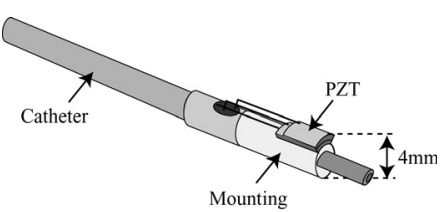

図 5 (b) Remote Haptic 型カテーテル センサの構成

Fig. 5. (b) Composition of RemoteType Haptic Sensor

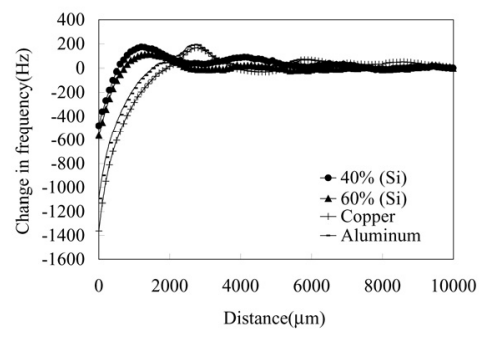

図 8 試料と周波数の関係結果

Fig. 8. Basic performance of the sensor

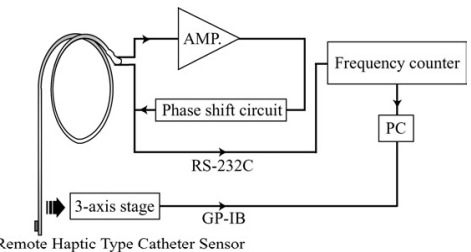

図 6 Remote Haptic 型カテーテル センサシステム

Fig. 6. Remote-Type Haptic Sensor System

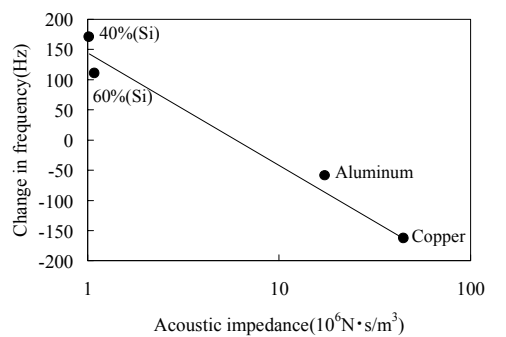

図 9 音響インピーダンスと周波数の 関係

Fig. 9. Relationship between acoustic impedance and change in frequency

\section{3. 計測システム}

〈3·1〉 Remote Haptic 型カテーテルセンサの構成

図 5(a)に，センサ部となる PZT の構成，及び図 5(b)は Remote Haptic 型カテーテルセンサの構成を示す。カテーテ ルセンサの構成はガイドフレームとしてカテーテル，セン シング機構としての PZT で構成されている。センサ部であ る PZT は送信部, 受波部の一対で構成し, 内筒・外筒から なる 2 個の円筒型 PZT を 4 分割して, 一部を長さ $5 \mathrm{~mm}$, 幅 $3.35 \mathrm{~mm}$ ，厚み $1 \mathrm{~mm}$ として Haptic 型に用いた。PZT はカテ ーテルの外側に図のように固定されるが，PZT 全体の振動 を妨げないようにシリコーンゴム上で保持した。また, PZT の絶縁処理はパリレンにより厚さ $3 \mu \mathrm{m}$ 程度のコーティング を施した。

尚, 本研究ではモデル実験による Remote Haptic 型カテー テルセンサの評価検討を目的としているが，血管内で使用 する場合には, PZT 素子の小型化や素子の固定法, 防水処 理法, 回路構成など, 解決すべき課題も数多くある。特に, 血管内で使用できるような超音波素子には PZT 全体の小型 化が望まれるが，PZT 素子の小型化に伴う放射音圧強度の 低下や検出感度の低下, 更には共振周波数の上昇などが重 要な問題となる。また, 本研究で使用している現在の位相 シフト法の発振回路では, $500 \mathrm{kHz}$ 以下の共振周波数で駆動 するように構成されているので, カテーテル内で使用でき るように PZT 素子を小型化すると, 共振周波数は $1 \sim 10 \mathrm{MHz}$ の高周波領域に上昇することになり，現在使用しているア ナログ的な位相シフト回路を採用することが困難となる。 従って, 数 $\mathrm{MHz}$ 領域でも使用できるように DDS (direct digital synthesizer) やDSP (digital signal processor) などによ るデジタル信号処理を導入して解決することが望まれる。 しかし，ここでは位相シフト法による強制帰還型発振回路 系の動作周波数の条件から，500kHz 以下の周波数領域で検 討を行うが, 基本的なシステム構成や硬さや軟らかさの画 像化については, 考察上問題とならない。ただし, PZTを カテーテルに実装して駆動するための保持材の厚みや, 保 持方法等についての条件については種々検討する必要があ る。

〈3・2〉 Remote Haptic 型カテーテルの構成 図 6 は カテーテル全体の計測システムを示す。検出信号である周 波数変化量はセンサ部 OUTPUT から RS-232C 接続により周 波数カウンタ（マイコンロジック社製）を介してコンピュ ータにて信号処理解析を行った。Remote Haptic 型カテーテ ルの検出特性を解析するためにモデル実験を行ったが，カ テーテルの先端部の移動制御には GP-IB を介した 3 軸ステ ージ (Chuo PRECISION INPUSTRIAL CO., LTD.) を使用し た。

一般に, 超音波による計測では, 対象物体となる血管壁 までの距離計測も重要となるので, 本システムを血管内で の計測に適用する場合, 送受波素子をパルス駆動して対象 物までの距離検出ができるようにすることが望まれる。尚, 本実験においては 3 軸ステージによる距離制御を行ったが, 血管内での計測には別途，パルス超音波による距離計測方 法についても検討をしている。

\section{4. 実験方法及び結果}

〈4・1〉 PZT による Haptic 型センサの基本特性 PZT 


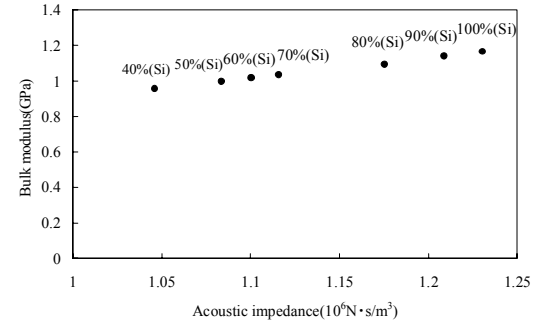

図 10 体積弾性率と音響インピーダンスの関係

Fig. 10. Relationship between bulk modulus and acoustic impedance

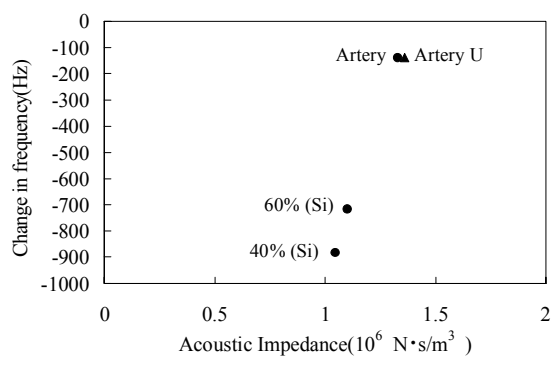

図 12 音響インピーダンスと周波数変化量の関係

Fig. 12. Relationship between acoustic impedance and change in frequency

による Haptic 型センサの基本特性について基礎的な実験検 討を行うために，硬さが既知のシリコーンゴムを用いて周 波数と硬さの関係についてモデル実験を行った。計測は水 中で，センサと試料が接触する直前を $0 \mathrm{~mm}$ とし $10 \mu \mathrm{m}$ 刻み でセンサを $10 \mathrm{~mm}$ まで平行移動して各移動位置における周 波数変化を計測し，3 回の実験を実施した（図 7)。使用し た試料のモデルは, シンナー (ShinEtsu RTV) により濃度 （重量比）を調整したシリコーンゴムブロック (ShinEtsu KE-116) 40\% [音響インピーダンス : $1.045\left(10^{6} \mathrm{~N} \cdot \mathrm{s} / \mathrm{m}^{3}\right)$ （以 下 $40 \%(\mathrm{Si})$ と表記 $) ， 60 \%$ [音響インピーダンス : $1.1\left(10^{6} \mathrm{~N}\right.$ ・ $\left.\left.\mathrm{s} / \mathrm{m}^{3}\right)\right](60 \%(\mathrm{Si}))$, 銅板, アルミニウム板の 4 種類である。

図 8 はそれぞれの移動距離における試料と周波数の計測 結果を示す。このときの周波数変化量は, 反射波の影響が 無い状態での共振周波数を基準として，対象物からの反射 の影響を考慮したときの共振周波数からの差として解析さ れた值を示す。結果は各試料について 3 回計測の平均值で, このときの周波数変化量は Haptic 型センサの移動と共に定 在波的な周期と振幅を持ちながら収束していく様子が認め られる。また, 各移動位置における試料ごとの周波数変化 量には振幅差が認められる。実験結果においては, 計測地 点 $2670 \mu \mathrm{m}$ に代表されるように伝播媒体のインピーダンス をべースに周波数変化方向が決定されるためインピーダン スが低い物質ではマイナス方向から，高い物質の場合プラ ス方向からの変化となり移動距離に対する周波数変化は対 称的になる。しかし，0 $\mathrm{\mu m}$ から $1290 \mu \mathrm{m}$ 間において銅板，ア ルミニウム板がシリコーンゴムと同じような傾向を示し た。

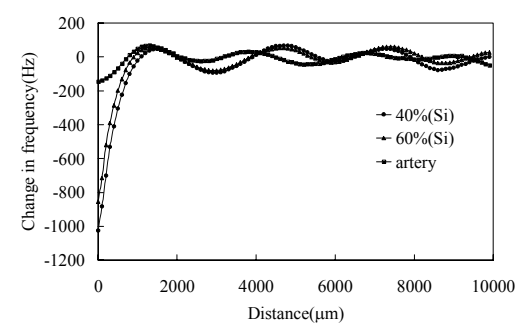

図 11 シリコーンゴムと血管の移動距離に対する周波数 変化量

Fig. 11. Change in frequency to move distance blood vessel and silicone gums

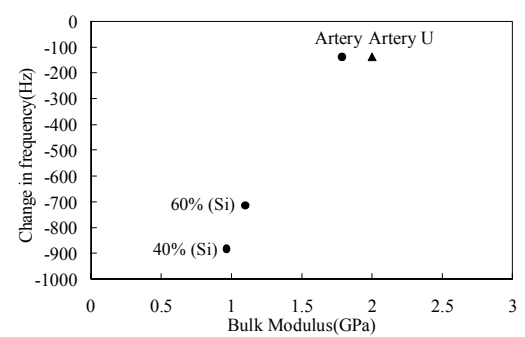

図 13 体積弾性率と周波数变化量の関係

Fig. 13. Relationship between bulk modulus and change in frequency

計測位置を $1300 \mu \mathrm{m}$ としたときの周波数変化と音響イン ピーダンスの関係を図 9 に示す。音響インピーダンスと周 波数変化量の関係は線形性を示し, 相関係数として $R^{2}=$ 0.8953 の傾向が得られたが, 銅やアルミなどの金属と軟ら かいシリコーンゴムでは周波数変化量に大きな差が認めら れる。このときの周波数変化量は $40 \%(\mathrm{Si})$ において 171.28(Hz)，60\% (Si)においては 111.125(Hz)，アルミニウム は-58.31(Hz)，銅は-162.25(Hz)を示した。周波数変化量の 関係は $40 \%(\mathrm{Si})>60 \%(\mathrm{Si})>$ アルミニウム>銅であり, 音響イ

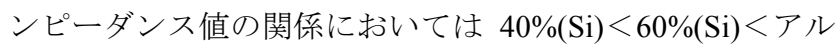
ミニウムく銅の関係を示すことから周波数変化量の大きさ と相関傾向は音響インピーダンスに密接な関係を持つこと が示されている。

〈4·2〉ブタ動脈血管組織の硬さ計測 $40 \%(\mathrm{Si})$, $60 \%(\mathrm{Si})$ による周波数変化量及び音響インピーダンス值から 摘出したブタ動脈血管組織の音響インピーダンス值を周波 数変化量による算出を試みた。実験方法は図 7 と同様に行 った。

図 10 には計測試料の校正值を得るために行った音響イン ピーダンスと体積弾性率の計測值を示す。計測法は送波用 圧電セラミック素子に印可電圧 $100 \mathrm{~V}$, 発振周波数 $1 \mathrm{MHz}$ (Panametrics 社) のパルス波を与えて, 受波用センサ (Panametrics 社製 PI25-3) との間に試料を挟み音速を測定 し，このときの試料の密度を求めることで音響インピーダ ンス及び体積弹性率の算出(21)を行った。

図 11 はセンサの移動距離に対するブタ動脈血管組織 (Artery) とシリコーンゴムの周波数変化量を示す。周波数変 


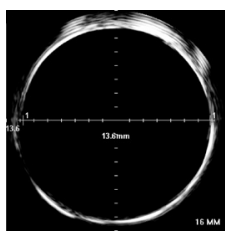

図 14 IVUS による血管 モデル内の様子

Fig. 14. IVUS image of blood vessel phantom

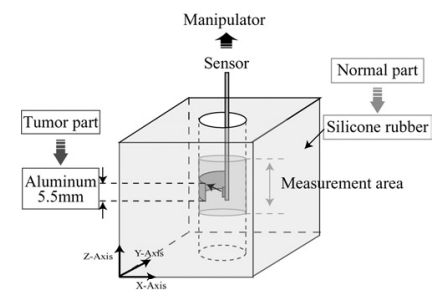

図 15 血管ファントム

Fig. 15. Blood vessel phantom

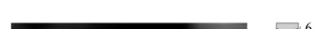

(a) Unfold bulk modulus

(b) 3D bulk modulus image

図 16 Remote Haptic 型カテーテルセンサによる血管 ファントム計測結果

Fig. 16. Acoustic impedance image of the using Remote-Type Haptic Catheter Sensor

化量は Haptic 型センサの移動距離の増加と共に，定在波で ある周期性と振幅特性を持ちながら収束していく様子が認 められる。また, 音響インピーダンスが未知のブタ動脈血 管組織は周波数変化量が，40\%(Si)>60\%(Si)>動脈の順であ り, 周波数変化量の変化方向より伝播媒体（水）の音響イ ンピーダンスより低くなることから微小な定在波に伴う周 波数変化量を示す。

図 12 は計測位置 $100 \mu \mathrm{m}$ における対象物の音響インピー ダンスと周波数変化量の関係を示す。結果は $40 \%(\mathrm{Si})$ におけ る音響インピーダンス值 $1.045\left(10^{6} \mathrm{~N} \cdot \mathrm{s} / \mathrm{m}^{3}\right)$ と周波数変化量 $-882.3188(\mathrm{~Hz}), 60 \%(\mathrm{Si})$ における音響インピーダンス值 1.1 $\left(10^{6} \mathrm{~N} \cdot \mathrm{s} / \mathrm{m}^{3}\right)$ と周波数変化量 $-715.075(\mathrm{~Hz})$ を用いて, 直線近 似によりブタ動脈血管組織の周波数変化量について対応を 示したものである。また，濃度別のシリコーンゴムは周波 数変化量と音響インピーダンスが線形関係を示すことから 周波数変化量が大きくなる軟らかい試料として $40 \%(\mathrm{Si})$, 60\%(Si)のシリコーンゴムを用い，また血管壁のように硬い ものの周波数変化量から求めたときの近似直線から音響イ ンピーダンスを算出の可能となる。これらの結果より, ブ タ動脈血管組織である Artery の音響インピーダンスを近似 的に求めると血管の音響インピーダンスは $1.328\left(10^{6} \mathrm{~N}\right.$ ・ $\left.\mathrm{s} / \mathrm{m}^{3}\right) \pm 0.0028\left(10^{6} \mathrm{~N} \cdot \mathrm{s} / \mathrm{m}^{3}\right)$ として得られる。ここでブタ動脈血 管組織の Artery U の近似值は超音波透過法により算出した 音響インピーダンス $1.3594\left(10^{6} \mathrm{~N} \cdot \mathrm{s} / \mathrm{m}^{3}\right)$ に近い值を示した。

なお, 計測距離が $1 \mathrm{~cm}$ の場合, 移動距離 $100 \mu \mathrm{m}$ における 分解能は $2363 \pm 14.703\left[\mathrm{~Hz} /\left(10^{6} \mathrm{~N} \cdot \mathrm{s} / \mathrm{m}^{3}\right)\right]$ となるが, 本実験で は安定的なシリコーンゴムの試料を用いて得られた周波数
変化量をもとに数值計算から求められている。従って, 分 解能や計測レンジの定量化は臨床実験等による検討から求 める必要があるものの, 基本的な計測システムの構成傾向 は十分認められる。

図 13 はシリコーンゴム及びブタ動脈血管組織の体積弾性 率と計測部位 $100 \mu \mathrm{m}$ における周波数変化量との関係を示 す。結果のグラフは 40\%(Si) [体積弾性率 : $0.965 \mathrm{GPa}$ ）と $60 \%(\mathrm{Si})$ [体積弾性率 : $1.1 \mathrm{GPa}$ ]より得られた直線近似の計 測結果から求めた周波数変化量を用いて動脈の体積弾性率 (Artery) の推定值を示す。動脈の体積弾性率は $1.788 \pm 0.009$ （GPa）であり, 軟らかい物質では体積弾性率が高いものほ ど周波数変化量も増加する傾向を示すことが認められた。 結果に示されるように濃度別のシリコーンゴムは音響イン ピーダンスと体積弾性率において線形関係を示すことか ら，パルス透過法による血管の体積弾性率 (Artery U) は $2 \mathrm{GPa}$, 周波数変化量からの推定結果では $1.78 \pm 0.009 \mathrm{GPa}$ と なり近似した值となるので本計測法の妥当性が認められ た。ただし，このような体積弾性率における評価では複雑 な軟組織の硬さの違いを検出できることは認められたが, 臨床に適応するには校正試料であるシリコーンゴムの評価 について計測の再現性や詳細な検討が必要となる。

〈4·3〉血管モデルを用いた計測＼cjkstart血管ファントムを 作成しセンサの有用性についての検証をモデル実験により 実施した。図 15 に示す血管ファントムは血管正常部位をシ リコーンゴム（体積弾性率：1.097GPa）, 硬化部位に典型的 なモデルとして材料定数が明らかなアルミニウムの試料を 用いた。実験は，水で満たされた血管ファントム内におい て径方向に $1 \mathrm{~mm}$ 離れた地点から $2 \mathrm{~mm}$ まで, $0.1 \mathrm{~mm}$ 移動の 距離で腫瘍部を通過するように Haptic 型カテーテルを配置 し，血管モデル内を $\mathrm{Z}$ 方向に $0.1 \mathrm{~mm}$ 刻みで $24 \mathrm{~mm}$ までセン サを移動させ, 各移動位置におけるセンサの位相計測を行 った。また, IVUS (VOLCANO In-vision Gold) による血管 モデル内における腫瘍部位の様子を図 14 に示す。画像より 血管モデルの内腔は真円であること, また, 画像上部は腫 瘍部位に位置するところであり輝度が高くなっていること が確認できる。

図 16(a)は Haptic 型カテーテルによる血管モデルの計測結 果を示す。結果のカラーバーにおける変化量は管内での体 積弾性率を示す。 $\mathrm{Z}$ 軸の移動に伴い $\mathrm{Z}$ 軸 $7 \mathrm{~mm}$ から $16 \mathrm{~mm}$ 付 近において体積弾性率が増加している箇所が各X軸移動に おいても認められた。このときの体積弾性率は, シリコー ンゴムの計測結果から求められた值であるが, 計測位置と 周波数変化量から求められた結果は, 正常部位より腫瘍モ デルの体積弾性率が高い物質であることから腫瘍部位の特 性を示したものと考えられる。しかしながら，腫瘍部位の 実測值の硬さは予測值よりも小さい值を示した。また, 困 16(b)にX 軸 $1.1 \mathrm{~mm}$ 地点における体積弾性率の值を用いて, モデルの形状に合わせた硬さ 3D モデルを作成した結果を 示す。このように位相シフト法によって非接触で正常部位 と疾患部位の硬さの違いや硬さのレベルを求めて, 画像化 
することが可能となる。

\section{5. まとめ}

本研究では Haptic 型カテーテルによる硬さ評価について 検討を行った。実験結果より Haptic 型カテーテルの周波数 変化量は計測試料の音響インピーダンスと相関性があるこ とが認められた。また，血管の音響インピーダンスをシリ コーンゴムの音響インピーダンスを用いることで周波数変 化量より定性的に推定できること，同様に弾性率について の相関性も認められた。また，血管ファントムによるセン サの有用性について基礎的な実験をおこなった結果，周波 数変化量のシフトの違いにより体積弾性率の大小関係を示 すことも認められた。しかし, 腫瘍部位の体積弾性率の実 測值は予測值よりも小さい值を示したが，この原因は腫瘍 部位における周波数変化量の実測值が超音波を送受信する 圧電セラミックの指向性や試料表面の不均一性などによっ て影響を受けているためと考えられる。しかしながら，こ こに得られた実験結果より硬さ評価が可能で，非接触法に よる Haptic 型カテーテルの開発についての可能性が示され た。

\section{謝 辞}

本研究の遂行において助言を頂いた東北大学未来科学技 術共同研究センターの江刺正喜教授, 東北大学先進医工学 研究機構の芳賀洋一教授, 松永忠雄助教に感謝の意を表し ます。

尚, 本研究は文部科学省・都市エリア産学官連携促進事 業（発展型）「郡山エリア」の助成（平成 18-20 年度）によ つて行われました。ここに深く感謝の意を表します。

(平成 19 年 4 月 25 日受付，平成 19 年 7 月 30 日再受付)

\section{文献}

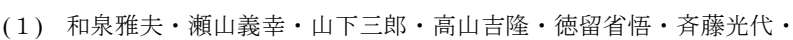
荒井親雄・長谷川元治：「ヒ卜大動脈硬化に関する研究一動脈壁成分 の多変量解析による検討一」, 動脈硬化, Vol.18, pp.775-782 (1990)

（2）林 幹男·徳留省悟・瀬山義幸:「動脈エラスチンの部位差について: エラスチン画分の架橋，疎水性，共存フィブロネクチンの差および これらの相関関係」，日老医会誌，Vol.34,pp.998-100 (1997)

（3）林 幹男・越阪部徹・牛尾房雄・瀬山義幸 :「七下動脈石灰化部位に おけるエラスチンの質的変化について」, 日老医会誌, Vol.36, pp.404-407 (1999)

（4）藪下博史・辻本俊和・林 孝浩・石川鉄司: 「OCT」, Heart View, Vol.3, pp.58-63 (2006)

( 5$)$ B. N. Potkin, A. L. Bartorelli, J. M. Gessert, R. F. Neville, Y. Almagor, W. C. Roberts, and M. B. Leon : "Coronary artery imaging with intravascular high-frequency ultrasound,Cardiology Branch, National Heart", Lung, and Blood Institute, National Institutes of Health, Bethesda, Maryland 20892. Circulation, Vol.81, pp.1575-1585 (1990)

(6) 高山忠輝・本江純子・斎藤 穎: 「急性冠症候群の非責任病変の観察」, Heart View, Vol.3, pp.34-37 (2006)

（7）松岡 宏・川上秀生・中村真扸・小松次郎・伊藤武俊：「CABG 後の vein graft disease $\rfloor$, Heart View, Vol.3, pp.43-51 (2006)

（8）林 孝浩: 「IVUS と血管内視鏡との対比」, Heart View, Vol.3, pp.52-57 (2006)

（9）陳 俊傑・江刺正喜・大城 理・千原國宏・芳賀洋一：「血管内低侵 襲治療のための前方視超音波イメージャーの開発」, 生体医工学, Vol.43, pp.553-559 (2005)
(10) 那須賢哉・土金悦夫: Virtual histology, Hart View, Vol.10, No.3, pp.74-80 (2006)

(11) M. Kawasaki, H. Takatsu, T. Noda, K. Sano, Y. Ito, K. Hayakawa, K. Tsuchiya, M. Arai, K. Nishigaki, G. Takemura, S. Minatoguchi, T. Fujiwara, and H. Fujiwara : "In Vivo Quantitative Tissue Characterization of Human Coronary Arterial Plaques by Use of Integrated Backscatter Intravascular Ultrasound and Comparison With Angioscopic Findings", Circulation, Vol.105, pp.2487-2492 (2002)

(12) 椎名 毅・山岸 正和: 「IVUS Elastography」, Hart View, Vol.10, No.3, pp.89-93 (2006)

(13) E. I. Cespedes, C. L. de Kortel, A. F. W. van der Steen, B. Norde, and K. te Nijenhuis: "Tissue mimicking material and image artifacts in intravascular Elastography”, IEEE ULTRASONICS SYMPOSIUM, pp.1181-1184 (1996)

(14) 根岸七雄 : 硬度触覚センサーによる腹部大動脈瘤壁の硬度と病理組 織学的検討」, 上原記念生命科学財団研究報告集, Vol.17, pp.396-398 (2003)

(15) S. Omata and Y. Terunuma : "New tactile sensor like the human hand and its applications", Sensors and Actuators, A, Vol.35, pp.9-15 (1992)

(16) 吉田 隆: 超五感センサの開発最前線, 株式会社 エヌ・ティーエス, pp.321-330

(17) Y. Murayama, C. E. Constantinou, and S. Omata : "Remote Sensing ofMechanical Properties of Materials Using a Novel Ultrasound Transducer and Signal,Processing", IEEE transactions on ultrasonics, ferroelectrics, and frequency control, Vol.52, No.3, pp.439-444 (2005)

(18) M. Haruta, Y. Murayama, and S. Omata : "Development of new ultrasound catheter for measuring the stiffness of tumor in blood vessel", 21TH sensor symposium, pp.423-426 (2004)

(19) M. Haruta, Y. Murayama, Y. Haga, and S. Omata : "Development of a catheter type tactile sensor using phase shift technology", Wc2006, pp.4457 (2006)

(20) 大崎順彦：「振動理論」, pp.32-35

（21）超音波便覧，丸善（株），pp.420-421 (1999)

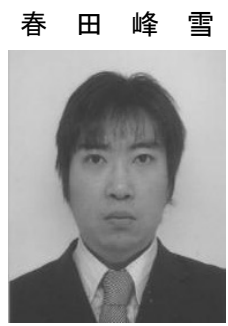

（非会員） 1978 年 10 月 29 日生。1997 年 3 月 日本大学工学部卒業。2003 年日本大学工学部博 士後期課程に入学。現在, 位相シフト法を用い た触覚センサの医療応用に関する研究に従事。

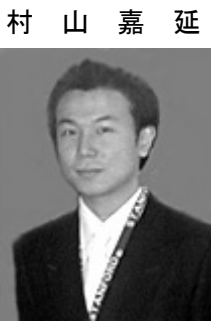

(非会員) 1976 年 6 月 16 日生。 2001 年 3 月大 阪大学大学院基礎工学研究科システム人間系 修了。博士 (工学)。2001 年 4 月日本大学工学 部助手を経て 2007 年同大学専任講師。現在, ヒト生殖補助医療（ART） 八向けた卵子の品質 評価システムの開発に従事。日本生体医工学 会, 日本産科婦人科学会, 日本不妊学会, 日本 受精着床学会, 日本哺乳動物卵子学会, IEEE。

尾股 定夫 (正員) 1947 年 10 月 16 日生。1974 年 3 月日

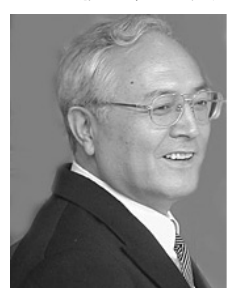
本大学大学院工学研究科修士課程修了。1981 年日本大学工学部専任講師。工学博士。助教授 を経て 1995 年同大学教授, 2005 年スウェーデ ン王立ウメ习大学名誉博士。現在, 次世代の医 療機器開発に関する研究に従事。日本生体医工 学会, 日本音響学会, 日本バイオレオロジー学 会, 日本機械学会, IEEE, 次世代センサ協議会, 日本超音波医学会, 日本ロボット学会。 